\title{
Heritage, Islam, Europe
}

\section{Entanglements and directions. An introduction}

\author{
Mirjam Shatanawi, Sharon Macdonald and \\ Katarzyna Puzon
}

In looking at heritage, Islam and Europe, this volume seeks to productively trouble all of these terms and throw new light on the relationships between them. In this way, it contributes fresh insights to existing debates in heritage and museum studies, and to the discussion of Islam in Europe.

The position and role of Islam in Europe is contested - especially as it intersects with ideas of heritage. On the one hand, Islam is frequently depicted as not properly European, or as at odds with what are claimed to be European values or European heritage. On the other, however, are arguments that Islam has long been part of Europe and should, therefore, be seen as part of European heritage; or that the many and diverse heritages of those who currently live in Europe - whenever and from wherever they arrived - should today all be regarded as part of the continent's and its various national heritages.

The notion of Islam itself is also contested. Is it a religion, a tradition, or a culture? Or a civilisation, a premise that undergirds most museum representations? Is Islam characterised by internal 'difference, diversity and disagreement' - or the opposite? Can, and should, a distinction be made between 'Islam' (the religion, as an unchanging universal core) and 'Muslim culture' (its fallible human interpretations) - positions that some see as diametrically opposed (e.g. Ahmed, 2016; Jouili, 2019)? Some European Muslims have argued that such a distinction is especially important to make in the face of the current negative public representations of Islam. And what are the presuppositions and effects of 'Islamic heritage' (see also Rico, 2017)?

In this volume, we examine such debates, highlighting how particular ideas of Islam, heritage and Europe are variously mobilised at different times and in different places, and looking at how they play out in specific instances. To do so is to take all of the terms of our title not as designating fixed entities but, rather, as subject to diverse interpretations, and as changeable and changing. At the same time, however, we are interested in when and how these may be stabilised (as well as opened up), by whom and in what ways. In particular, we are concerned with how they are materialised through infrastructures, practices and processes, such as those of museum taxonomies, buildings and sites, exhibitions, rituals, and creative reworking of traditional forms. Thus, our contributors variously look both at official sites of heritage, such as museums and designated heritage buildings, including not only some mosques, but also those, for example, sacred landscapes and cemeteries, that 
are not so designated but are nevertheless regarded by their participants as of current value and having significant continuities with the past. Moreover, we expand our scope still further to also encompass practices bound up with senses of self that invoke the past, such as particular deployments of music, sound or scent. By opening up heritage in this way, Islam and Heritage in Europe also suggests ways in which heritage itself might be rethought.

As well as looking at a broad array of forms of heritage, contributors to the volume also discuss cases in many different European countries, including Bosnia and Herzegovina, France, Germany, Montenegro, the Netherlands, Russia, Spain, Turkey and the United Kingdom. The geographical scope is, however, broader still, for the people, heritages and Islams involved interconnect in various ways with other parts of the world, inside and outside Europe. Temporally, our emphasis is on the present, but this takes us back into the various pasts that are mobilised as heritage, as well as to those that exert continuing influence in the present. This includes colonial histories, which are implicated in the bringing of certain objects to museum collections, as well as many Muslims to Europe, not least in recent so-called refugee crises.

As the subtitle of our book - Pasts, Presents and Future Possibilities - indicates, our concern is also to look at what has been and is underway in order to consider what might be potentials for both research and practice in the future. Below, we initiate this by providing broader context for the chapters that follow, as well as introducing the chapters themselves.

\section{The heritage of Islam in Europe}

Heritage from the Muslim world has been entering European collections since the time of the Crusades, accumulating over centuries in vast collections in museums, libraries and private homes across the continent. Muslims have had a long historical presence in al-Andalus and in medieval Sicily, as well as in Southeast Europe and Russia, where they remain significant minorities within the population. More recently, postcolonial and workforce migration, together with the seeking of refuge and asylum, have brought them to many more European countries, leading not only to a larger but also to a more varied Muslim presence in the continent. To give an indication of numbers: in 2016, 4.9\% of Europe's population was estimated to be Muslim, with figures ranging from $0.2 \%$ or less in Poland, the Czech Republic, Slovakia and the Baltic states, to $11.1 \%$ in Bulgaria, $8.8 \%$ in France and $8.1 \%$ in Sweden. ${ }^{1}$ The recent migrant experience has also led to a tendency, especially in Western and Northern Europe, to consider Muslims in Europe primarily through the lens of migration, contributing to a widespread tendency to equate Muslims with migrants (e.g. Brown, 2000; Shryock, 2019), overlooking the fact that Islam has played a part in Europe's history and culture for centuries.

The longstanding presence of Islam in Southern and Eastern Europe gives an alternative potential for heritagisation than does the more recent presence in Western Europe (see, for instance, McMurray's chapter in this volume). This does not necessarily mean that Islam will become part of the mainstream national heritage in those countries where it had a longer presence. For most of the formerly 
socialist countries of Southern and Eastern Europe, the rebuilding of national identities since the 1990s has usually excluded giving much attention to Islamic heritage. Indeed, as Jesko Schmoller (this volume) describes for the case of Russia, emphasis on the Christian Orthodox Church - or, rather, on a specific church that becomes the national one, tends to leave Muslims as marginalised as they were during socialist times, or even more so. ${ }^{2}$ Interestingly, even an ideology of Eurasianism, in which Russia explicitly positions itself between Europe and Asia, which might in theory have allowed Islam to also be cast as part of Russian identity, does not overcome this. Nevertheless, they continue their practices, though, as Schmoller argues, this should not be seen as some kind of identity politics - that is, as some kind of publicly active resistance.

Islamic heritage has also played a part in building distinctive identities in the post-socialist and post-Balkan-War period. For those countries that formerly belonged to the Ottoman Empire, and today have substantial Muslim populations (most notably Albania, Bosnia and Herzegovina, Bulgaria and the Republic of North Macedonia), this includes Ottoman heritage (Adie, 2019; Bryce \& Čaušević, 2019; Merdjanova, 2013; Velioğlu, 2013). Muslim holy places are also important heritage sites for South European Muslims, such as the Ajvatovica, a place of annual pilgrimage and Europe's largest Muslim gathering near Prusac in Bosnia and Herzegovina (Henig, 2012; Rujanac, 2013). Even within and between these countries, however, there remains considerable ambivalence over Islamic heritage (see especially Velioğlu, 2013) - with which 'Ottoman' is, not unproblematically, often regarded as synonymous. ${ }^{3}$ In Skopje, capital of what since 2019 is officially called the Republic of North Macedonia, for example, some proposed restoration of Islamic architectural heritage has met with local resistance owing to a strong association of Islam with the neighbouring enemy, Albania (Dimova, 2019). Likewise, in 2020, the Louvre cancelled a forthcoming exhibition about Bulgaria's Ottoman past, following concern from Bulgarian lenders over the curatorial framework, which focused on stylistic dialogues between Christian and Islamic art (Greenberger, 2020). Such disputes are not necessarily new, however. Michael Herzfeld's classic study, A Place in History: Social and Monumental Time in a Cretan Town (1991), shows local people objecting to what they see as official attempts to preserve 'Turkish' architectural features. In Turkey itself, Ottoman heritage - as architecture and art - has a chequered history (see Karaca, this volume; Shaw, 2010). In recent years, however, the Ottoman past has become increasingly - if still unevenly - celebrated, revived especially by conservative Islamist politics, often playing into a political rejection of European identity, though sometimes into its selective embracing (Bozoğlu, 2019; Bozoğlu \& Whitehead, 2018; Girard, 2015; Göle, 2015).

Within Southern Europe, Spain has most enthusiastically and prominently although nevertheless ambivalently - embraced an Islamic heritage (Arigita, 2013; Astor, 2017; Mediano, 2013). The Iberian Peninsula, and the period of al-Andalus (711-1492), has attracted much attention of scholars interested in translocality of heritage, including questions of 'shared heritage' (Civantos, 2017), Spain's colonial project (Calderwood, 2018) and dealing with its various legacies (Arigita, 2013; Hirschkind, 2014; Puerta Vilchez, 2010). As Avi Astor shows in his chapter in this 
volume, the vaunted revival of al-Andalus has not led to a widespread embracing of contemporary Islam and Muslims, or of Islamic heritage elsewhere in the country. While it would probably be too strong to argue that the very fact that Andalusia is considered to have such a rich Islamic heritage feeds into other parts of Spain ignoring it, the case clearly shows how limits are set on how far even a much admired Islamic heritage comes to be seen as part of wider national or European heritage. Elsewhere too, a flagging up and even celebration of Muslim presence and Islamic heritage in some parts of a country - perhaps even certain cities, such as Bradford in the United Kingdom being colloquially referred to as 'Bradistan' on account of its population connected with Pakistan (see McLoughlin, 2014) - risks being double-edged, leading to ghettoisation rather than inclusion.

It should also be recognised that heritage has played an important role in the discourses and practices that Muslims and Muslim 'communities' mobilise to negotiate Islam's place in Western Europe. Mosques, through their visibility and audibility, mediate between the public and the private, the secular and the religious. They can also be agents of transformations - and what might be seen as 'new' heritage-making - in an urban context, as Petra Kuppinger $(2015,2019)$ shows in her examination of the Salam Mosque complex in the German city of Stuttgart.

\section{Transcending Europe's borders}

Islam in Europe is connected beyond the imagined geographical borders of Europe through multiple kinds of entanglements. These include those of transborder movements of people through migration - recent or longer ago - as well as continuing connections, such as through relatives or wider faith-based communities, as well as through ideas and imaginaries. The very notion of the ummah - to designate a world community of Muslims - is thoroughly translocal, transcending nations as well as regions (e.g. van derVeer, 2002). How it is understood and lived in practice may well vary between groups and localities, of course, but even as an idea, it clearly evokes belonging beyond more limited territorialisation (Merdjanova, 2013; Puzon, this volume). So too does a Muslim cartography that not only gives special significance to certain locations, especially Mecca, but also requires that 'people of Muslim heritage' - to use an increasingly frequently used formulation - visit these. Hajj pilgrimage to $\mathrm{Mecca}$ - is, as such, part of a thoroughly translocal and indeed global heritage practice in which Muslims in Europe, as elsewhere, may participate. In addition, heritage tourism to Islamic sites is a global phenomenon, supported by a wide range of organisations. These include the Islamic Educational, Scientific and Cultural Organization (IESCO), established in 1979, modelled on and offering a significant alternative to the United Nations Educational, Scientific and Cultural Organization (UNESCO). ${ }^{4}$ Like its counterpart, IESCO gives attention to cultural heritage, having proclaimed the 'Islamic Declaration on the Protection of Cultural Heritage in the Islamic World' in 2017 and established an Islamic World Heritage List. While its list of 132 sites does not include any within Europe, there are other organisations dedicated to preserving Islamic heritage, which are also based outside Europe but that have provided funding for the restoration of heritage within it. The Turkish 
Cooperation and Coordination Agency, TIKA, established in 1992, has been especially influential - its Islamic Heritage programme funding the restoration of mosques in Balkan countries (Kersel \& Luke, 2015). ${ }^{5}$ Companies specialising in Islamic heritage tourism visits to Europe from other parts of the world have also developed, with Spain being the most popular destination but halal tours are also offered in Portugal, Bosnia and Herzogovina, Russia, Greece and Italy (Adie, 2019).

In several European countries, cultural institutions have been established to strategically advance cultural relations with the Arab states. These institutions frequently use the medium of the exhibition, with a special focus on contemporary art and photography, as tools for cultural diplomacy. In 2006, a consortium of Spanish governmental bodies founded the Casa Arabe, with branches in Madrid and Cordoba, whereas the private A.M. Qattan foundation runs the Mosaic Rooms in London. Casa Arabe presents itself as a meeting point where different stakeholders can 'dialogue, interact, establish lines of cooperation and undertake joint projects' (http://en.casaarabe.es, for more examples of cultural diplomacy in Spain, see Astor, this volume). The Institute du Monde Arabe (Arab World Institute, IMA) in Paris was founded in 1980 by 18 Arab countries together with France (see Guidi, this volume). In addition, the Institut des Cultures d'Islam (Cultures of Islam Institute, ICI), also based in Paris, but city-financed, wants to be 'a place for dialogue and learning' about the diversity of the cultures of Islam in the world (https://www.institutcultures-islam.org/). Like the IMA, the ICI largely focuses on Islamic cultures abroad rather than on French Muslims, in line with the French official state policy of perceiving all citizens as French without making a distinction based on ethnic origin or religious affiliation.

\section{The idea of Europe}

That Islam has played a significant and even key - if often unrecognised or ignored - role in imagining the very idea of Europe has been argued by many scholars. Edward Said's Orientalism (1978) established what became an influential and widespread analytical approach in which representations of 'the Orient' were understood as being fundamentally about European self-definitions. Not least because Said's 'Orient' principally drew examples from the Middle East, Islam was thoroughly part of the oriental 'Other' against which Europe defined itself. Within the broad and often ambiguous span of emotions evoked by this Other, Said argues that fear and a sense of threat have long been to the forefront. 'For Europe', he writes, 'Islam was a lasting trauma' (1978/2003, p. 59) - a lurking danger that could imperil 'the whole of Christian civilisation' (ibid.).

Building on this, Talal Asad poses the question 'Muslims and European Identity: Can Europe represent Islam?' (2002). As he puts it: 'The problem of understanding Islam in Europe is primarily... a matter of understanding how "Europe" is conceptualized by Europeans' (2002, p. 209). Through a selection of contemporary historical narratives, he shows how these variously position Muslims as 'in Europe but ... not of it' (2002, p. 213). In some cases, this is by historical accounts that equate 
Europe with Christendom, or, later, Judeo-Christianity, ${ }^{6}$ deploying tropes such as 'civilisation' to evoke a continuing 'essence of Europe', with Islam thus cast as the fundamental other. Also exclusionary are historical narratives of Europe that focus on conflict within the continent - as applies especially to many World War I and II narratives - and ignore entanglements beyond it. What these produce is a teleological account in which contemporary Europe emerges autochthonously, in triumph over its own internal conflicts. This runs alongside the positioning of Islam as 'Other', simultaneously bolstering an image of Europe as autonomous and pristine, with other presences and histories - especially those of the colonial - side-lined or ignored.

There is no doubt that such historical narratives are crucial to how Europe is imagined and to who can thus be defined as, or can be allowed to feel, 'European'. As Asad notes and other scholars have also elaborated, such narratives have been deployed in the establishment of, and debates over, the expansion of the European Union (Berger, 2009; Macdonald, 2013). In relation to the possible accession of Turkey, the issue of its 'Europeanness' has been especially questioned, with Islam a major reason given or implicit (Delanty, 2013; Göle, 2012, 2015; MacMillan, 2013). An important part of Asad's argument, however, is that at issue is not just the question of which narratives are told but also the key concepts and formations of ideas that inform them. He regards a particular discourse of 'identity' - one bound up with Lockean notions of property and inheritance - as promoting the idea of 'real Europeans [who] acquire their individual identities from the character of their civilization' while at the same time as implying that 'not all inhabitants of the European continent are "really" or "fully" European' (2002, p. 217). He acknowledges, however, that the word 'civilisation' - which plays a key role in this articulation - does not have wide public traction, though, as we see below, it is frequently deployed in museums. The idea and practice of heritage, however, which he never mentions, can provide a means for such narratives to permeate society more widely. Moreover, it shifts the parameters of debate still further.

\section{Heritage and 'the idea of Europe'}

Putting 'heritage' into Asad's argument shows how the ideas of Europe with which he is concerned can be disseminated and naturalised. Heritage as a term and a format - in which certain histories are given contemporary value - has become, especially over the past two decades, internationally widespread, and, importantly, not only in relation to 'high culture' but also at local, popular and vernacular levels. What it entails is not simply historical narrative - though this is typically part of it - but a close linking with identity. Heritage is always attached to some group - some social collective: there is always a 'whose' of heritage (Eriksen, 2014; Macdonald, 2013, 2018).

Unlike 'civilisation', heritage operates at multiple scales. It can be deployed not only with reference to large-scale entities, as is civilisation, but also at more micro ones, not only national but sub-national, even of small localities or special interest groups. Thus, categories such as 'European heritage' or 'Islamic heritage' are used 
as well as, say, 'Syrian migrant heritage' or 'Bosnian Muslim heritage'. Moreover, these various kinds of heritage can be overlapping or subsumed within each other: they can be non-exclusive. This contributes to a widespread democratisation of heritage, in which it is increasingly not only used in reference to - or left in the hands of - elites but is also taken up by many various groups and to multiple different, and sometimes contradictory, ends. Scholarship - especially what has come to be called critical heritage studies - has both reflected and supported this, casting its net all the more widely to incorporate more and more forms under the label of 'heritage' - as, indeed, we do in this book.

This development has a number of implications. On the one hand, it means that there is now potentially an even more effective route for consolidating particular ideas of Europe - including ideas in which Islam is positioned as 'Other'. 'European heritage' turns Europe not just into an idea but also into a landscape filled with material and immaterial 'evidence' of an identity-relevant past. On the other hand, however, it allows for a recognition and flourishing of multiple other heritages, potentially subsisting together, at different scales - rather than just in the model of clashing or serially superseding civilisations. While this does not eliminate the persistence of majority conceptions of Europe, it allows for the manifestation of others, including alternatives or even those that run counter to the majority ones. That is, it also opens up to widespread acceptance of the idea of a multitude of diverse, minority identities and heritages. This goes some way towards establishing a model in which Asad's call for a 'Europe in which everyone lives as a minority among minorities' (2002, p. 226) is at least more thinkable. Equally, however, it remains clear - as contributions to this volume abundantly evidence - that majority heritage and accompanying practices of exclusion continue across the continent.

Nevertheless, what these reflections and the contributions to this volume also imply is that attending only to majority ideas of Europe would be to miss important parts of the picture. While there is no doubt that 'fortress Europe' - a conception in which the continent is seen as needing to maintain forceful guard of its boundaries against incursion, especially Muslim - has considerable continuing, and indeed even increasing, currency, it is not the only imaginary in operation, even within Europe's political and cultural centres of power. Not only have there been alternative conceptions - including some that are more accommodating of Islam as part of Europe (Delanty, 2013; Fadil, 2019) - in the past, but there are also significant variations across the continent, as already noted. Furthermore, over the last decade in particular, even promoted by the relatively European mainstream - such as the European institutions and governments of Western Europe - there have been multiple political statements and the creation of narratives in which Islam is included as part of Europe (Bock \& Macdonald, 2019; Puzon, this volume). Especially relevant for the present volume is that many of these do so by positioning Islam as part of Europe's heritage. As heritage is an especially powerful mode of inclusion - a format with widely acknowledged legitimacy and value - this allows for Islam to be historically situated within Europe rather than simply accepted as being present in the here and now. As heritage, in other words, Islam becomes a valued cultural form, and as part of European heritage, it gains the potential to 
become of rather than just in Europe. It becomes part of 'where we have come from' and not simply 'what we are now'.

Therein, however, lies heritage's 'rub'. That very past-orientation of heritage also allows for making a distinction between the past and today in which 'where we have come from' might also potentially be 'what we no longer are' or even 'what we have left behind'. Thus, considered as part of heritage, Islam may be seen as having contributed to shaping Europe but that does not necessarily mean that Muslims living in European countries today will feel included. Indeed, as various chapters in this volume show, such heritage can even be used to the contrary, to act as a 'better' form of Islam, in relation to which contemporary Muslims and their practices are held as lacking. A heritage of 'good Islam', that is, can make today's Islam seem all the more, instead of less, alien (see, e.g. Guidi, and Shatanawi, this volume).

Europe, then, we argue, needs to be seen as globally entangled and multiply imagined and reimagined - processes in which heritage and Islam are thoroughly and mutually enmeshed. As such, Islam and Heritage in Europe contributes to a wider project of 'provincialising' (Chakrabaty, 2000) or 'decentering' Europe (e.g. Adam et al., 2019; Dabashi, 2019; Göle, 2012).

\section{Coloniality and heritage}

The movement of decentring Europe, in relation to Islam, is essentially a movement to overcome the legacy of European colonialism. In Europe and its Shadows: Coloniality after Empire (2019), Hamid Dabashi deals with Europe as a metaphor and traces how the condition of coloniality persists even after the collapse of empires - museum taxonomies are but one example. Dabashi argues that this condition "with the European "West" on one side and the colonized "Rest" on the otherhas now metastasized', and the world has entered a new phase in which the coloniser and the colonised are no longer divided along any national, regional, or continental divide (Dabashi, 2019, pp. 193-194). What results, he says, is the decentering and deauthorising of Europe globally, in a 'new montage', and the opening up of Europe to the world at large. Various contributions to this volume discuss the implications of this development at a local level, whereas other chapters outline the legacy of colonial-period constellations and suggest directions for their transformation.

At the peak of European imperialism, the British, Dutch, French and Russian Empires each governed more Muslims than any Muslim-ruled state, including the Ottoman Empire. The most obvious consequence of this was the large-scale movement of works of art, objects and even entire architectural structures from the colonised Muslim lands to the European metropoles. The Islamic art collections in France, Britain and Russia were largely formed in colonial contexts, but museums in countries without colonies in Muslim regions, such as Germany, also benefited from the steady stream of objects coming out of the colonies (Gierlichs \& Hagedorn, 2004; Giese, Volait \& Varela Braga, 2019; Vernoit, 2000). In recent decades, the restitution and repatriation of colonial collections has become an area of increasing debate. Remarkably, Islamic art has thus far remained relatively in the shadows. There are several reasons for this, such as the greater weight many countries in the 
Muslim world place on the cultural heritage of pre-Islamic civilisations (Feener, 2017) and the relatively more urgent situation regarding Sub-Saharan African heritage. ${ }^{7}$ Nonetheless, a few claims on Islamic objects have been put forward, mostly by Turkey, against museums such as the Louvre (Güsten, 2011).

Colonial paradigms continue to have profound influence on how these collections are being displayed in museums in Europe. The nineteenth-century arrangement of collections broke up Middle Eastern history and heritage into three time periods (pre-Islamic, Islamic, and modern). Each of these time periods was studied in a different disciplinary tradition (archaeology, art history, and ethnology, respectively) and the corresponding collections became part of dedicated museums (Shatanawi, this volume). The taxonomies and conceptions of Islamic collections (including definitions of the 'Islamic') have remained largely unchallenged since the early twentieth century (Karaca, this volume). Likewise, artefacts from the ancient Near East remain not only geographically, but also epistemically dislocated and detached from the region where they were once excavated (Brusius, this volume). Moreover, the different time periods were, and still are, appreciated and appropriated differently; generally, Near Eastern archaeology and Islamic art were valued more, and seen as closer to Europe, than the heritage of modern and contemporary Muslims. In addition, colonial concepts did not lead to the appreciation of Islamic art everywhere in Europe. The largest colony of the Netherlands, Indonesia, had a predominantly Muslim population. Yet Indonesia came to be seen in Dutch museums, academia and popular culture, as part of a single Asian civilisation with Hindu-Buddhist and spiritual characteristics (Bloembergen \& Eickhoff, 2020; Formichi, 2016).

Colonialism has also resulted in the creation of Islamic heritage in Europe as a result of Muslim migration. For instance, the Great Mosque of Paris, inaugurated in 1926, was built to serve the needs of Muslims originating from the French colonies (Bayoumi, 2000). Furthermore, post-independence migration has led to new forms of heritage, for example, pious art forms and the reshaping of cultural expressions (Peter, Dornhof, \& Arigita, 2013). Chapters in this volume, especially those by Katarzyna Puzon, Peter McMurray and Jesko Schmoller all provide instances of this, highlighting the broad range of forms that these might take, and, in the process, showing how heritage itself is expanded and diversified through such processes.

\section{National approaches to diversity}

In addition to differing colonial legacies, also varying between European countries are laws and policies that seek to regulate approaches to cultural and religious difference. While there have been useful attempts by scholars to identify 'national models' of how difference is approached (see Choquet, 2017) - ranging from its attempted erasure through assimilation to its toleration or even celebration, it is important to emphasise that there may be considerable change over time and variety within legal and policy landscapes, even to the extent that inconsistencies arise. Questions of Islam and heritage are not necessarily (and are indeed unlikely to be) covered by a single law or policy but instead fall under laws and policies variously devised to address citizenship in general or more specific areas, including religion and culture 
(within which heritage legislation and policy are more specific still). In addition, different levels of law and policy may be in operation simultaneously, emanating not only from national governments but also from supranational organisations such as the EU and UNESCO, as well as from more local, regional or city governance. How far these shape what actually happens on the ground is itself also notoriously varied, as chapters here, especially that of Schmoller, also underline.

With these caveats in mind, it can nevertheless be usefully pointed out that some countries primarily favour integration, that is, emphasising collective values and downplaying difference (even outlawing certain manifestations of it), whereas others accept and may even support religious and cultural diversity through forms of multiculturalism. Usually, France is taken as the prime example of the former, though even there, this does not entail extensive restrictions on religious and cultural expression outside the public sphere. Moreover, as Diletta Guidi's chapter here shows, the French approach certainly does not rule out displaying Islamic heritage. On the contrary, doing so, especially in national institutions, can contribute to the centralising agenda by promoting a 'frenchified' form of Islamic heritage that conforms to national values. Multicultural models ostensibly not only tolerate the manifestation of cultural and religious difference but even give state support for some expressions of it - with heritage especially likely to be so recognised. Here, the Netherlands and the United Kingdom are the usual exemplars of nations adopting multicultural policies, with both usually being said to have done so in part to respond to Muslim populations (Bertossi, 2011; Modood, 2013). Again, however, this has gone alongside more integrationist tendencies rather than supplanting these. Moreover, both countries, alongside various others in Europe, have seen a 'backlash' against multicultural approaches since the early 2000s (Modood, 2013; van Reekum et al., 2012; Vertovec \& Wessendorf, 2009). Indeed, both countries' governments in the early 2000 s proposed new national history museums to help instil more national values in the face of what was claimed to be the 'failure' of multiculturalism (Macdonald, 2016). Elsewhere in Europe too, there are often complex and changing mixtures of approaches. Greater religious freedom in most post-socialist contexts has sometimes allowed for the flourishing of Islam (Račius, 2018), alongside other religions, though not necessarily (Schmoller, this volume), and perhaps accompanied by increased state control (Račius, 2020). As we also see in this volume, however, while national governments may seek to instrumentalise heritage to fit with prevailing policy approaches - of which the chapters by Astor and Guidi provide the strongest examples, though even here this is not unequivocal - this is far from all-pervasive, not least because heritage is also shaped by the very presence of collections (including with specific colonial histories and entanglements), sites and people that may push in other directions.

\section{Contestations of Islam in Europe}

What we see clearly in this volume, then, is that there is no single 'European' position on Islam and Islamic heritage. Whether Europe is even imagined as having a single heritage or multiple heritages is not a constant across time or space. These 
are important caveats to arguments about Islam playing the role of the Other in constituting Europe as a predominantly Christian space. As we have noted and will see in various chapters that follow, these arguments are certainly not without substance: there are many contexts in which Muslims find themselves positioned as very much as neither of nor belonging in Europe, not least those of the populist nationalisms discussed below. But these ways of positioning Islam also need to be considered alongside others, which manifest a good deal of variety not only across different European countries but also within them. Degrees of rejection and acceptance are not equally distributed across populations and they change over time, as well as being variously inflected in different cultural spheres and in relation to different kinds of imagined Islam. Such differences matter not only to help gain a fuller picture but also because they too shape the lived experience of and with Islam in European societies.

That having been said, there was a widespread increase in anti-Muslim sentiments across Europe, and indeed worldwide, after the terrorist attacks of 11 September 2001. Following those and subsequent tragic events, such as the terror attacks in Madrid in 2004, the London bombings of 2005, and the Berlin Christmas market attack of 2016, Islam was most prominently featured in public debate in relation to terrorism. Elsewhere, as in the case of Chechnya, Islamophobic campaigns have been launched against secessionist movements. More recently, especially during the 'refugee crisis' of 2015 and 2016, increased Islamophobia has been witnessed in many countries (e.g. Kaya, 2020), including those with very small Muslim populations (Bobako, 2017).

Heritage - perhaps figured as 'tradition' or 'culture' - is often central to contested aspects of Islam in Europe. Veiling (Moors, 2012; Abu-Lughod, 2013), minarets (Göle, 2011), the azan (call to prayer) and attitudes towards figurative images (Tamimi Arab, 2017, and forthcoming) have all, variously, been depicted in the media as rooted in 'traditional culture', and used as exemplars in discussions over whether Islam can - or should - find a place in Europe. In 2019, as part of the campaign for the European elections, the German nationalist AfD party (Alternative for Germany) placed posters across the country that were a 'reinterpretation' of JeanLéon Gérôme's 1866 painting 'The Slave Market'. The posters showed a naked white woman surrounded by men wearing Arab headdress, and featured the slogan 'Europeans, vote for AfD! So that Europe does not become a "Eurabia"'. Pointing to the imaginary 'Orient', they evoked representations rooted in Orientalist discourses supported by the 'us' versus 'them' rhetoric. At the same time, however, heritage has been mobilised to challenge anti-migrant attitudes and anti-Muslim prejudice. For example, in Amsterdam, designers collective Mediamatic developed a line of Arab products in the style of the 'typically Dutch' department store Hema, including a redesign of the logo which was rebranded EL HEMA.The HIPSTER/ MUSLIM project (2014-2019) involved a series of portrait photographs of hipsters and Muslims, with the identical beard as starting point. The photographs were exhibited outdoors in the urban settings of Brussels, Antwerp, Rotterdam and Amsterdam to start a conversation on identity and stereotyping. In addition, museums have sought to challenge problematic representations of Muslims in many and various ways as we see below and elsewhere in this volume. 


\section{Museums and Islam in Europe}

Since the events of 11 September 2001 and the rise of anti-Muslim sentiment, there has been an increased interest of museums in the West in presenting Islamic art and material culture. Across Europe, museums have invested in new galleries, or their existing collection displays have undergone a major overhaul (for a partial list see Shaw, 2019a). In major metropolitan institutions, notably the Louvre in Paris and the British Museum andVictoria \& Albert Museum in London, these remakes were made possible by sponsorship coming from the Muslim world, in particular the Gulf countries and Southeast Asia. Yet, despite the renewed interest in exhibitions, research on how Islam is transmitted, displayed and framed through museum representations remains relatively scarce (Grinell, Berg \& Larsson, 2019). This is remarkable considering the interest of critical museology in issues of social justice, and the focus on museums as spaces to counter prejudice and to confront racial discrimination (e.g. Gonzales, 2020; Janes \& Sandell, 2019; Labadi, 2018; Sandell \& Nightingale, 2012).

In Europe, Islam is mostly presented in museums through Islamic art, a category of art that was created by European art historians around the turn of the twentieth century, grouping together objects from Central and West Asia and North Africa on the basis of stylistic similarities. Islamic art is often defined as 'the visual culture of any society where Muslims were or are dominant', and the category also includes the art made by or for Muslim groups in societies where they constituted minorities (Watenpaugh, 2017). Major Islamic art collections can be found in museums across the continent (for an overview see Ådahl \& Ahlund, 2000), for instance, in Austria (Vienna), Belgium (Brussels), Denmark (Copenhagen), Ireland (Dublin), Germany (Berlin, Hamburg), Greece (Athens), France (Paris), Portugal (Lisbon), Russia (Moscow, St Petersburg), Spain (Granada, Madrid), Switzerland (Geneva, Zurich), Turkey (Istanbul) and the United Kingdom (Cambridge, Edinburgh, London, Oxford).

The idea that there is something like 'Islamic art' is deeply embedded in modernist, European discourse rather than in Islamic concepts. As Wendy Shaw (2019b, p. 11) explains: 'Islamic art history has often designated a history of objects produced under Islamic hegemony and considered through lenses crafted to define the "Western" legacy: art, aesthetics, and dynasties. This is a history of objects recognized as art and understood in analytical terms from a vantage point dependent on European intellectual history'. Modernist European principles, privileging aesthetics over function and secularising the concept of art, can be found in most definitions of Islamic art that museums commonly provide. Therefore, an 'Islamic' work could be designated purely on stylistic criteria, regardless whether it has a relationship to the Islamic religion or not.

Initially the term Islamic art was used for a limited range of objects. In the twentieth century, the canon of Islamic art gradually expanded to include a wider geographical and temporal reach. Today the category of Islamic art comprises, as the Calouste Gulbenkian Museum in Lisbon clarifies, 'objects made from Spain to India, from the time of the Prophet Muhammad to the eighteenth century'. The starting 
point is Islam as a cultural and civilisational zone. Islam is here explained in the sense of 'Islamicate cultures' (Hodgson, 1974), to refer to the cultural layers of the regions ruled by Muslims, which are influenced by Islam but not necessarily religious in themselves. According to this canon, Islamic art is said to end in the nineteenth century, coinciding with the beginning of European colonisation of the Muslim world and the birth of its disciplinary study (Flood, 2007; Watenpaugh, 2017). Following from this art historical format, the central message of Islamic art galleries focuses on stylistic and material features (e.g. metalwork, ceramics, textiles, calligraphy, miniature painting) and their development over time (the dynasties under whose guidance the items were produced). Exhibition texts usually only briefly touch on religious and social aspects of the Muslim world (Grinell, 2020, p.36).

A second mode of museum presentation also defines Islam as a culture and civilisation, but focuses instead on its social aspects. This type of exhibition can be found in ethnographic museums and other categories of cultural history museums, where objects are usually presented under geographical headings, such as the 'Middle East' or 'North Africa'. These modes of presentation are also present in Europe's Muslim majority countries and regions, for example, in Bosnia and Herzegovina, where they are current in museums showcasing national or regional cultures. Thematically, this type of exhibition addresses topics like religious rituals, social classes, gender roles and the differences between city and countryside.

Museums where Islam is primarily exhibited as a religion, rather than an art historical category or a civilisation, are few. Notable exceptions are the gallery dedicated to Islam at Glasgow's St Mungo Museum of Religious Life and Art, which was inaugurated in 1993 (Kamel, 2013; Naguib, 2015), as well as the Religionskundliche Sammlung in Marburg and the State Museum of the History of Religions in St Petersburg (Orzech, 2020). The colonial past could also be one of the prisms through which collections are presented, as it is intimately tied up with the histories of collections, especially in Western Europe, which are often the result of colonial encounters, but this background is largely ignored in museum presentations of Islamic collections (Kamel, 2019).

\section{The study of museum representations of Islam}

Following the pioneering volume Discovering Islamic Art: Scholars, Collectors and Collections, 1850-1950 (Vernoit, 2000), there has been a steady rise of research on the histories of collecting Islamic art and material culture in Europe. These publications often focus on one collector or museum, or they take a national approach. Together they cover a wide geographical range, including countries such as Poland, Russia, Romania and Hungary (e.g. Dolezalek \& Guidetti, forthcoming; Gierlichs \& Hagedorn, 2004; Giese et al., 2019; Kadoi \& Szántó, 2013). However, when it comes to questions of how museums present Islam and Muslims today, and how historical collecting practices impact contemporary representational politics and identity formation, research is concentrated on Western Europe. Moreover, within this part of Europe, only a limited range of countries is covered: the United Kingdom and Germany (see, e.g. Heath, 2007; Kamel, 2013; Kamel \& Gerbich, 2014), 
the Netherlands (Shatanawi, 2012a, 2012b, 2014), and France (Bernasek, 2007, 2010; Guidi, 2019). Within this body of literature, the main focus is on Islamic art in national and encyclopaedic museums, while less attention has been paid to the presentation of Islam and Muslims in other types of museums, for example, those with holdings of ethnographic material or contemporary art and in city and neighbourhood museums.

The focus on Western Europe has a number of implications, as it means that the place of Islam in museums is studied through the lens of postcolonial and labour migration and as a minority culture, rather than with an eye on the Muslim communities that have been living in Europe for centuries. Another research theme that follows from this focus, concerns the colonial roots of collections of Islamic art and material culture in Western Europe. Past research has focused on colonial encounters through objects, the durability of colonial epistemologies through canon formation and the construction of taxonomies, as well as on the impact of these historical processes on museum representation today (see the various contributions in Journal of Art Historiography, June 2012; Junod, Khalil, Weber, \& Wolf, 2012; Vernoit, 2000). Specifically, critical debate has focused on the untimely 'death' of Islamic art around 1900 which, by consequence, locates Islam's greatest achievements in the past and ignores its contributions in the modern period (Flood, 2007; Graves, 2012). More recently, the growing research interest in ways in which museums address religion has resulted in a number of studies about the religious aspects of museum representations of Islam, in particular Muslim spiritual experiences, in museums in Western Europe (Berns, 2015, 2016; Reeve, 2017, 2018). Besides Western Europe, Turkey has a prominent place in research that is critically engaging with museum representations of Islam, with a focus on the question of how changing political attitudes towards the secularisation policies of the Turkish Republic govern museum practices (see, e.g. Harmanşah et al., 2014; Posocco, 2019; Shaw, 2010). Literature on Southern or Eastern European countries, on the other hand, but remarkably enough also on Scandinavia, is scarce or even absent.

\section{Exhibitionary emphases of Islam}

The portrayals of Muslims in cultural institutions in Europe 'tell us much about how Europe is understood, maintained and imagined' (Larsson \& Spielhaus, 2013, p. 106). As Diletta Guidi outlines in her contribution on France in this volume, museums in Europe employ different 'exhibitionary regimes' in their portrayal of Islam and of Muslims, which can be seen as two distinct (if overlapping) emphases that run in parallel and compete with each other. To a large extent, these emphases are framed by the type of collections museums possess as well as the specific missions and roles they seek to fulfil. Almost all exhibitions discuss Islam and Muslims through the 'management of difference' (Whitehead \& Bozoğlu, 2015), that is, they construct 'Europe' and 'Islam' as distinct and separate cultures, and subsequently they set out to emphasise difference between the two entities, to either marginalise Islam or to assimilate it. 
In national and encyclopaedic museums, Islam is typically staged through masterpieces of Islamic art, presenting Islam as a civilisation that is distant from Europe in time and place. The historical nature of the Islamic art collections comes with a number of drawbacks. The make-up of the Islamic art collections, with the majority of objects originating in Central Asia, the Middle East and North Africa rather than in the Muslim regions of Europe, and their temporal frame, predating the modern and colonial era, precludes a narrative which presents Islam as integral to European heritage. Policy makers, and also the public, expect these exhibitions to address issues relevant to present-day Europe, such as the twentieth-century migration from Muslim countries, the rise of political Islam and the position of Muslim women (Demerdash-Fatemi, 2020). Yet, the historicity of the objects and the art historical prism through which they are interpreted makes museums ill-suited to reflect these recent interests and, as a result, they hardly accommodate the public's growing demand for better insight into Muslim history and societies (Heath, 2007). Instead, Islamic art exhibitions present objects in a frame of tolerance, that is, the displays intend to teach visitors to respect, admire, and become intrigued by the beauty and wisdom produced in the Islamic world, which is situated far away and in the past (Larsson, 2019). Nonetheless, in a number of national museums, one can find a narrative which shows Islamic culture as historically intertwined with and contributing to the cultural past of Europe and to specific national histories, as is the case of the Museum of Islamic Art in Berlin (Spielhaus, 2013) and the Louvre in Paris (Guidi, this volume).

Another type of exhibitionary emphasis focuses on contemporary Islam and Muslims and their relation to European culture. In Western European museums, this regularly involves the celebration of multiculturalist and cosmopolitan cultures and an intercultural treatment of Muslim otherness, based on the accentuation of similarities and differences to promote common living. Whitehead and Bozoğlu (2015, p. 254) give the example of exhibition displays about the presence of Turkish communities in the urban centres of Germany and the Netherlands, and observe: 'we see Turkish people and cultures utilized to construct a kind of ideal cosmopolitanism associated with a hybridisation of cultural identities and forms (e.g. cuisine) that characterize a beneficial Western-European multiculturalism'. Similarly, exhibition displays of this kind draw parallels between Christianity, Judaism and Islam, pointing out the shared origin of the three religions, in order to promote tolerance and co-existence (Guidi, this volume). The Ottoman past is sometimes employed in a similar scheme of positive re-interpretation of history to promote common living. For example, it is remarkable that in many of the new Islamic art galleries, Armenian works of art are displayed with reference to the multireligious and multicultural make-up of the Ottoman population. Yet as Banu Karaca (this volume) explains, the same galleries remain silent on the state violence, dispossession and the displacement of Armenians and their material culture in the late Ottoman period.

A third type of exhibitionary emphasis presents Islam and Muslims as integral to Europe's history and Muslims as a natural component of Europe's population. This type of narrative is, however, more rarely encountered. Of particular interest in this respect are the museums located in the Muslim-majority countries and regions of 
Europe, such as Bosnia and Herzegovina where museums offer competing narratives of the position of Muslim culture vis-à-vis other religious and cultural communities in the region (von Puttkamer, 2016). In Western Europe, museums led by Muslims have only recently been created, for example, in Spain and Switzerland. ${ }^{8}$ In these Muslim-led museological settings, Islam is no longer presented as foreign, but as 'diasporic', because objects are used for self-representation oriented towards contexts that are at once national and supra-national, for example, the ummah or the Middle East as well as Africa (Rey, 2019).

Research in the United Kingdom and Germany shows that exhibitions representing the lives and perspectives of Muslims living in Western Europe today tend to happen outside the large metropolitan museums: in city museums, local libraries and neighbourhood and community museums (Kamel \& Gerbich, 2014; Reeve, 2017). Small locally based museums have a number of advantages. They are less bound by the conventions of academic disciplines such as art history or archaeology, which makes it easier to collect new material relevant to the lives of Europe's Muslim citizens and to address current questions, including those related to migrant experiences and a specifically European Muslim religiosity. Furthermore, they are more likely to engage new audiences through outreach work or by becoming a meeting place and discussion forum for local citizens (Puzon, 2019). Nevertheless, as we discuss in the final chapter of this volume, such developments are also, increasingly, evident in larger and even national museums.

\section{Bridging cultures in museums}

As noted above, negative images of Islam and Muslims prevail in the news media, political discourse and public perceptions throughout much of Europe. In contrast, museum representations of Islam and the Muslim world typically focus on positive aspects. As Göran Larsson (2019, p. 11) observes, 'museums in Europe are governed by the notion that they should combat what they see as negative and stereotypical images in society'. In addition, museums have expressed that they want to 'promote dialogue', 'create understanding', or 'build bridges' between Europe and the world of Islam. Museums, thus, take on the position of broker, which emanates from some of the roles they assume for themselves: to make society a better place and to spread beauty to the world. The more direct response of museums to current affairs also has to do with the fact that governments and funding bodies increasingly ask museums to prove their relevance for today's societies.

In a much-cited essay, Jessica Winegar (2008) analyses Islam-related arts events in the United States after 11 September 2001. Her main argument holds that cultural institutions promote an understanding of Islamic history and cultures that converges with political discourses departing from a clash of civilisations between the West and the Islamic world. Museums and other cultural institutions aim to build 'bridges of understanding', but in doing so, they hold on to their own norms as to what kind of art, and what kind of underlying political idea, makes an acceptable bridge, and by extension they hinder constructive dialogue from being fully realised. Much of Winegar's argument also holds for museums in Europe. Deniz Ünsal (2019) observes 
that the politics of recognition of migrant and refugee cultures translates more often into a conception of cultural difference akin to celebratory spectacle, for instance, through 'opening up museum spaces for the participation of diverse communities with their music, performance, food and art', and to the espousal of cultural integration rather than to deep engagement with some of the difficult questions arising from living together in difference. Cultural institutions tend to shy away from critically addressing the destruction the West has wrought in the Middle East, in the past or present, or the problems of Muslims living in the West in the face of anti-Muslim racism and Islamophobia. Few museums in Europe have staged exhibitions addressing the rise of Islamophobia heads on, as the exhibition Re:Orient-The invention of the Muslim Other (2019) did. The exhibition, curated by Anna Sabel und Özcan Karadeniz for the GRASSI Museum of Ethnology in Leipzig, examined the image of the Muslim in Germany from the days of nineteenth-century orientalism up to the anti-Islam Pegida movement and recent violent attacks on German citizens of Middle Eastern descent. Equally important, the highlighting of 'good' (beautiful, peaceful and humanising) aspects of Islam inevitably evokes its counterpart of 'bad' (destructive, aggressive and fanatical) Islam. As Winegar (2008, p. 677) asks: 'Can the emphasis on art as evidence of humanity really erase stereotypes of Middle Eastern Muslims as un-human destructive terrorists, or does this framing depend on these stereotypes for its own definition and execution?' The reality of representation leaves museums in a catch-22 situation: the idea of dialogue and bridge-building evolves out of the idea of two irreconcilable cultures and 'museums looking for alternatives in an attempt not to assert, but rather subvert the thesis of the clash of civilisations have very few options' (Shatanawi, 2012a, p. 192).

More than 10 years after publication, Winegar's assertions still seem to hold relevance in the European situation, as is evidenced by the multiple references to her essay throughout this volume. But are there options for museums to get out of this representational crisis suggested by Winegar and others? One way is to present Islam in a networked model, showing the links between religions, cultures and countries, as Sharon Macdonald (2014) has suggested. Macdonald cites the Museum with No Frontiers (http://www.museumwnf.org, MWNF), an online museum in which cultural institutions from 36 countries in Europe as well as the Middle East and North Africa (MENA region) collaborate, among other examples of presentations which avoid the two-civilisation mode. Mirjam Brusius' contribution to this volume argues for a much more intense involvement of Europe's Muslim communities with museum work. This will lead to an engagement with Islam as a lived and living tradition, and will also bring the networked experience centre stage. Here, other possible understandings of heritage that Islamic ideas and practices suggest - as articulated by Wendy Shaw in her chapter below, and exemplified in different ways by the chapters of Puzon, McMurray and Schmoller - might also be drawn on to inform novel museological approaches.

Another model is to present Islam within other topics, rather than as a stand-alone civilisation in a dedicated exhibition or section (Macdonald et al., this volume). Such a model is followed by the Rijksmuseum in Amsterdam, where Islamic objects are scattered across different displays, such as the ceramics and armoury sections, and the 
galleries dedicated to the Netherlandish Middle Ages and Renaissance and the eighteenth century (Shatanawi, 2021). The choice to spread the Islamic objects positions the Muslim world firmly within the narrative of (art) history and positively emphasises its connections to Europe. In fact, various museums in Europe with only a few Islamic items in their collections opt for this approach, but mainstreaming Islam could be also worthwhile for museums with large collections of Islamic art and material culture. Temporary exhibitions also create excellent opportunities for this approach and several museums in Europe make Islam feature in themed-based displays. For instance, the Jewish Museum in Berlin regularly includes Islamic topics in temporary exhibitions with themes such as food or fashion.

\section{The chapters in this volume}

To further explore the entanglements and directions outlined above, this book brings together the disciplinary perspectives and vantage points of scholars from anthropology, art history, media studies and musicology, political science and sociology. Covering a wide range of cases, they collectively highlight various problematics. Furthermore, in their diversity and depth, they show the value of exploring heritage and Islam in Europe.

We have split the book into three sections, each of which is organised around one main theme that we recognise as vital to a critical investigation and better understanding of past and ongoing developments and future possibilities with which this volume is concerned. Part I deals with embodied heritage and senses of belonging manifested through sonic, fragrant and performative ways of engaging with aspects of Islam. Part II takes up the subject of nation-state and identity formations. The chapters discuss how the workings of the state - including state violence - play out in museum and heritage developments in different national contexts. Focusing primarily on museums, the contributions in Part III explore in various ways how older taxonomies and established, as well as newer, practices come together with contemporary social and political challenges. In doing so, they also point towards possibilities for new museum and heritage practice.

We begin with a chapter by Wendy Shaw who provokes us to draw on Islamic thought to rethink the very idea of heritage, as well as notions of the museum and objects with which it is entangled. Rather than operate in terms of 'the heritage of the Islamic world', she argues, we might try to imagine a concept of heritage that is Islamic. Reflecting on Platonic, Islamic and modern European discourses of perpetuating Truth through embodied form (as speech rather than as writing), her chapter identifies various modes of what she calls 'heritage messaging' and argues that the that dominant model of objective heritage preservation could be shifted towards models of embodied heritage perpetuation. This would in effect constitute a decolonising of the category of Islamic heritage, redefining it instead as perpetually re-emerging through the reconstruction of the past with an eye to the future. The museum would thus need to be re-envisioned to emphasise perpetuation over preservation, and to devise non-linear strategies 
of exhibition that stage multimedia and information in a complex matrix of forms of display.

The following three chapters all take up the theme, identified by Shaw as important within Islam, of embodied heritage. Peter McMurray's contribution explores how the social life of Islamic cemeteries is made manifest through sonic practices embedded in what he calls 'cemetery poetics', that is, norms and practices that govern interactions in those places. These include recitations, ritual prayers, and processional routes. Bringing together examples from Turkey, Germany, Montenegro and Bosnia and Herzegovina, McMurray reflects on different histories with regard to European Islam and ways in which Islamic cemeteries act as a rich medium for articulating those histories. He examines how sound shapes those places and how the past and the present intersect there. McMurray argues that this contributes to a better understanding of Muslim life in contemporary Europe, and shows how ethnographic listening can be incorporated more effectively into heritage studies as a critical interpretive lens as well as a research practice.

In her chapter, Katarzyna Puzon examines ways in which young Muslims of the i,Slam collective negotiate their belonging through the medium of poetry slam in the current German context, in which Islam is often contentious. Combining oral traditions of 'Islamic heritage' with a contemporary format of poetry performance, they engage in practices which entail seeking to make a difference, in the sense of causing change, and represent an embodied form of heritage-making that moves beyond the binary of 'here' and 'there'. Puzon shows how their slam poetry, along with other activities in which it is embedded, challenges a limited understanding of what it means to be German. Her contribution draws attention to questions that arise when Islam is put on stage in Germany - literally in the case of i,Slam's events but also more broadly - and what comes into play in these developments.

The lines of visibility and invisibility also play a role in the lives of the Uralic Muslim communities in Russia. Drawing on ethnographic research, Jesko Schmoller discusses the ways in which members of these communities create a space for themselves in a context in which national identity is officially defined by only one religion and one culture, that is, Orthodox Christianity and Slavic culture. In so doing, they mobilise the sense of smell and use fragrance (misk) in order to make 'visible' a neglected and seemingly forgotten Muslim culture. Schmoller discusses how this connects to the Islamic notion of 'the other world' (al-ghayb), exploring the role that fragrance plays for Muslims in Russia not only in facilitating the coming of a new world but also in addressing and dealing with their current situation within the nation.

The national political context is also central in Avi Astor's discussion of how Spain's rich Islamic heritage has been the object of national redefinition. He shows how, following Spain's democratic transition during the late 1970s, Islamic heritage was strategically deployed by political elites, urban planners, and business entrepreneurs. In a context of a small numeric presence of Muslim minorities, this continued through to the 1990s, resulting in large mosque projects and other initiatives aiming to render Spain's historical connection to Islam visible. As there were few significant political and social concerns regarding Spain's modest Muslim 
population, the 'Muslim question' was treated as a purely symbolic matter, divorced from the problems of integration that were beginning to take shape in other European countries. This changed, however, in the late 1990s and early 2000s due to rising levels of North African migration, as well as the terror attacks of 9/11 in New York and of 11-M in Madrid.

Diletta Guidi describes another context that is strongly defined by national policies: that of the national museums in Paris. According to Guidi, both the Louvre and the Institute du Monde Arabe (IMA) are involved with the production of images of the 'good' Muslim. The Louvre's Islamic art department exemplifies a first model as it filters out religious elements and 'frenchifies' Islam to present a picture of a secularised Islamic art that conforms to European art historical norms. Institutions like the IMA present another model, as they play what Winegar has named the 'humanity game'. The IMA projects a humanist image of the Muslim as part of its mission to create a bridge between the Arab world and the West. Its exhibitions leave out anything that could be seen as negative or dangerous, in order to produce the image of an Islam that is free, emancipated and modern, as well as successful and open-minded. To this end, the IMA uses examples of practices perceived as familiar and positive by the non-Muslim visitor to present Islam as a 'cool' religion and Muslims as a 'cool' community. However, the polished image of Islam, Guidi argues, is just as stereotypical as that of the fanatical terrorist.

Continuing a focus on museums, the following chapters engage with the heritage constellations of the past and the need to transform them towards future - more inclusive - practices. Mirjam Shatanawi's contribution looks at the taxonomies of Islamic and Middle Eastern collections that developed in European museums in the nineteenth century and continue to inform museum praxis today. She describes the historical process of the division of objects over different museum disciplines archaeology, art history and ethnology - in the Netherlands. Yet, as she explains, the Dutch situation is not unique: it has its pendants in museums all over Western Europe. The museum narrative of Islam and the Middle East thus developed implies a movement of inclusion and exclusion from Europe, in which the ancient pre-Islamic past is taken as Europe's own, pre-modern (or actually, pre-colonial) Islam is reluctantly and conditionally accepted and modern Islam perceived as a full outsider. Using structural injustice theory, Shatanawi argues that this narrative, and particularly how it positions contemporary Muslims, reproduces colonial inequalities and hinders the self-realisation of Muslims as European citizens.

Drawing on recent work of critical engagement with the category of Islamic art, Banu Karaca's contribution addresses state violence against non-Muslims in the late Ottoman Empire and the early Turkish Republic in the course of which works of art were expropriated, looted and displaced. Karaca argues that the formation of Islamic art, which happened concurrently, led to the de-emphasising of the contribution of non-Muslims to the art histories of Turkey's Ottoman and post-Ottoman periods, in favour of a homogenous national frame. The continuous disregard of museums of the violence and dispossession that is part of the biographies of some of the Islamic objects in their collections, stands in contrast with the 'bridges of understanding' the same objects are supposed to make. 
Focusing on instances of dispossessed art that are not captured by provisions against crimes against humanity, war crimes, and the conventions on the illicit trafficking of cultural property that have been elaborated by UNESCO and the EU, the chapter asks what historical justice might come to mean beyond the restitution of individual objects.

Mirjam Brusius also points out that many museum collections relating to 'Islamic heritage' are products of imperial expansion. As such, they play crucial roles in producing concepts of historical narratives, ethnicity, racial identity and difference. Current displays of Mesopotamian artefacts, for example, suggest a period of decline from the birth of Islam onwards, while European narratives link their historical present to mythical beginnings in the Middle East. Many European museums thus show the Middle East's past as part of European history, in relation to narratives of the 'cradle of civilisation' that first had to be 'discovered' by European archaeologists in the nineteenth century. Meanwhile, the excavations that were foundational for many collections are still rendered as triumphalist and heroic stories. As a result, ancient artefacts are historically disconnected from other histories, including Europe's imperial endeavours, and the resulting conflicts in the Middle East today. In light of this, the chapter asks what would be entailed in a decolonisation of archaeological artefacts from this region; and what might be done. Like Shaw, she argues that this requires a rethinking of how 'heritage' is currently conceptualised.This is needed, she points out, not least to respond to the demands of those who ask for new narratives that also reflect other senses of belonging and inclusion.

Our final chapter turns to a major turn in heritage practice that is directed towards providing such new narratives and senses of belonging. This is a turn to using participatory approaches to involve a broader range of participants - and especially involving those who might be less likely to visit museums otherwise. In the chapter, we discuss various such new initiatives - mainly in major state museums in Berlin - that in some way or other have involved Muslim participants and that held the potential to disrupt or counter some prevailing negative stereotypes. As the chapter shows, such initiatives face certain challenges - the acknowledgement of which can help in the development of future practice. At the same time, however, they are an important impetus for bringing new voices into the debate and thus contributing to re-framing Islam in museums and heritage in Europe.

By bringing these cases together, we hope not only to add more studies to the existing repertoire of research that is variously concerned with heritage, Islam and Europe but also to show the importance of considering these areas in concert to highlight their entanglements. By doing so, we also seek to illuminate new directions and possibilities for scholarship. Furthermore, as heritage is a field of practical activity - that reaches deep into lives and experiences, as well as into institutional structures and the making of selves and others - we hope that this book shows how this has been shaped in different parts of Europe, as well as how it might be reshaped in future. 


\section{Acknowledgements}

This book is based on the workshop Islam and Heritage in Europe. This was run and funded as part of the Representing Islam strand within the Making Differences: Transforming Museums and Heritage in the $21^{\text {st }}$ Century research project. The project was primarily funded by the Alexander von Humboldt Foundation as part of Sharon Macdonald's Alexander von Humboldt Professorship, with further support from the Humboldt-Universität $\mathrm{zu}$ Berlin, the Prussian Cultural Heritage Foundation and the Berlin Natural History Museum.

\section{Notes}

1 See the Pew report: https://www.pewforum.org/essay/the-growth-of-germanysmuslim-population/. As this explains, figures are not available for Balkan countries (accessed 23.5.2020).

2 Occasionally, in other parts of the Russian Federation following the break-up of the Soviet Union, the idea of a shared Islamic heritage has emerged as part of unifying imaginaries, as in Daghestan, where it remains significant (Kemper, 2014; see also Yemelianova, 2016).

3 The wording of the UNESCO World Heritage entry for Albania's Historic Centres of Berat and Gjirokastra is indicatively sensitive and diplomatic. It describes them as being of the 'Ottoman period' characterised by 'coexistence of various religions and cultural communities down the centuries', and 'a way of life which has been influenced over a long period by the traditions of Islam during the Ottoman period', http://whc.unesco.org/en/list/569 (accessed 11.4.2020). An emphasis on the multireligious and multiethnic nature of the Ottoman Empire has also been emphasised in Turkish secularity (e.g. Göle, 2015).

4 IESCO's website: https://www.icesco.org/en/. Its cultural heritage resource: https:// www.icesco.org/en/sustainable-protection-of-cultural-heritage-in-the-islamicworld/ (accessed 11.4.2020).

5 See also TIKA's website: https://www.tika.gov.tr/en (accessed 11.4.2020).

6 As Wendy Shaw explains, "Judeo-Christian” [is] a nineteenth-century term justifying racialized Protestant supremacy in Europe recycled in anti-fascist discourse of late 1930s North America to assimilate Jews into "Western" societies' (2019b, p. 9). As she notes of 'the "Western" artistic tradition', however, 'the Jewish is as absent as the Islamic' (ibid.).

7 The Sarr and Savoy report (2018) did not involve North Africa, because of the region's different histories of collecting and appreciation.

8 For instance, the Musée des Civilisations de l'Islam (MUCIVI) in La Chaux-de-Fonds, close to Neuchâtel, Switzerland, which opened in 2016, and the Museo vivo de Al-Andalus in Cordoba, Spain, a creation by the controversial French philosopher Roger Garaudy (1913-2012), a convert to Islam.

\section{References}

Abu-Lughod, L. (2013). Do Muslim women need saving? Cambridge, MA \& London, England: Harvard University Press.

Ådahl, K., \& Ahlund, M. (2000). Islamic art collections: An international survey. London: Routledge. Adam, J., Bojadžijev, M., Knecht, M., Lewicki, P., Polat, N., Römhild, R., \& Spiekermann, R. (Eds.). (2019). Europa dezentrieren. Munich: Campus. 
Adie, B. A. (2019). Marketing Europe to Islamic heritage tourists. In C. M. Hall \& G. Prayag (Eds.), The Routledge handbook of halal hospitality and Islamic tourism. Abingdon: Routledge.

Ahmed, S. (2016). What is Islam? The importance of being Islamic. Princeton \& Oxford: Princeton University Press.

Arigita, E. (2013). The 'Cordoba paradigm': Memory and silence around Europe's Islamic past. In P. Frank, S. Dornhof, \& E. Arigita (Eds.), Islam and the politics of culture in Europe: Memory, aesthetics, art (pp. 21-40). Bielefeld: transcript.

Asad, T. (2002). Muslims and European identity: Can Europe represent Islam? In A. Pagden (Ed.), The idea of Europe: From antiquity to the European Union (pp. 209-227). Cambridge: Cambridge University Press.

Astor, A. (2017). Rebuilding Islam in contemporary Spain: The politics of mosque establishment, 1976-2013. Brighton: Sussex Academic Press.

Berger, S. (2009). History and forms of collective identity in Europe: Why Europe cannot and should not be built on history. In L. Rorato \& A. Saunders (Eds.), The essence and the margin: National identities and collective memories in contemporary European culture (pp. 21-36). Oxford: Berghahn.

Bernasek, L. (2007). Representation and the republic: North African art and material culture in Paris (Unpublished $\mathrm{PhD}$ thesis). Harvard University.

Bernasek, L. (2010). 'First arts' of the Maghrib: Exhibiting Berber culture at the Musée du Quai Branly. In K. E. Hoffman \& S. G. Miller (Eds.), Berbers and others: Beyond tribe and nation in the Maghrib (pp. 171-194). Bloomington: Indiana University Press.

Berns, S. (2015). Sacred entanglements: Studying interactions between visitors, objects and religion in the museum (Unpublished PhD thesis). University of Kent.

Berns, S. (2016). Mobilising Mecca: Reassembling blessings at the museum. In T. Hutchings \& J. McKenzie (Eds.), Materiality and the study of religion: The stuff of the sacred (pp. 203-218). London: Routledge.

Bayoumi, M. (2000). Shadows and light: Colonial modernity and the grand mosque of Paris. The Yale Journal of Criticism, 13(2), 267-292.

Bertossi, C. (2011). National models of integration in Europe: A comparative critical analysis. American Behavioural Scientist, 55(12), 1561-1580.

Bloembergen, M. \& Eickhoff, M. (2020). The politics of heritage in Indonesia: A cultural history. Cambridge: Cambridge University Press.

Bobako, M. (2017). Islamofobia jako technologia władzy: Studium z antropologii politycznej. Kraków: Universitas.

Bock, J.-J., \& Macdonald, S. (2019). Introduction: Making, experiencing and managing difference in a changing Germany. In J.-J. Bock \& S. Macdonald (Eds.), Refugees welcome? Difference and diversity in a changing Germany (pp.1-38). Oxford: Berghahn.

Bozoğlu, G. (2019). Museums, memory and emotion: The affective politics of the past in Turkey. Abingdon: Routledge.

Bozoğlu, G., \& Whitehead, C. (2018). Turkish neo-Ottoman memory culture and the problem of copying the past. In B. Brenna, H. D. Christiansen, \& O. Hamran (Eds.), Museums as cultures of copies: The crafting of artefacts and authenticity (pp. 85-98). Abingdon: Routledge.

Brown, M. (2000). Quantifying the Muslim population. International Journal of Social Research Methodology, 3(2), 87-101.

Bryce, D. \& Čaušević, S. (2019) Orientalism, Balkanism and Europe’s Ottoman heritage. Annals of Tourism Research, 77, 92-105.

Calderwood, E. (2018). Colonial al-Andalus: Spain and the making of modern Moroccan culture. Cambridge, MA: Belknap Press of Harvard University Press. 


\section{Mirjam Shatanawi, Sharon Macdonald and Katarzyna Puzon}

Chakrabaty, D. (2000). Provincializing Europe: Postcolonial thought and historical difference. Princeton, NJ: Princeton University Press.

Choquet, S. (2017). Models of integration in Europe, Robert Schumann Foundation Policy Paper. https://www.robert-schuman.eu/en/european-issues/0449-models-of-integrationin-europe (accessed May 22 2020)

Civantos, C. (2017). The afterlife of Al-Andalus: Muslim Iberia in contemporary Arab and hispanic narrative. Albany, NY: SUNY Press.

Dabashi, H. (2019). Europe and its shadows: Coloniality after empire. London: Pluto Press.

Delanty, G. (2013). Formations of European modernity: A historical and political sociology of Europe. Houndmills: Palgrave Macmillan.

Demerdash-Fatemi, N. (2020). Objects, storytelling, memory and living histories: Curating Islamic art empathically in an era of trauma and displacement. In J. Norton-Wright (Ed.), Curating Islamic art worldwide: From Malacca to Manchester (pp. 31-44). Cham: Springer International Publishing.

Dimova, R. (2019). Elusive centres of a Balkan city: Skopje between undesirable and reluctant heritage. International Journal of Heritage Studies, 25(9), 958-973.

Dolezalek, I., \& Guidetti, M. (forthcoming). Heritage revisited: Rediscovering objects from Islamic lands in Enlightenment Europe. London: Routledge.

Eriksen, A. (2014). From antiquities to heritage: Transformations of cultural memory. New York: Berghahn Books.

Fadil, N. (2019). The anthropology of Islam in Europe: A double epistemological impasse. Annual Review of Anthropology, 48(1), 117-132.

Flood, F. B. (2007). From the prophet to postmodernism? New world orders and the end of Islamic art. In E. Mansfield (Ed.), Making art history: A changing discipline and its institutions (pp. 31-53). London: Routledge.

Formichi, C. (2016). Islamic studies or Asian studies? Islam in Southeast Asia. The Muslim World, 106(4), 696-718.

Gierlichs, J., \& Hagedorn, A. (Eds.). (2004). Islamic art in Germany. Mainz: Philipp von Zabern.

Giese, F., Volait, M., \& Varela Braga, A. (Eds.). (2019). À l'orientale: Collecting, displaying and appropriating Islamic art and architecture in the 19th and early 20th centuries. Leiden: Brill.

Gonzales, E. (2020). Exhibitions for social justice. London: Routledge.

Girard, M. (2015). What heritage tells us about the Turkish state and Turkish society. European Journal of Turkish Studies, 19.

Göle, N. (2011). The public visibility of Islam and European politics of resentment: The minarets-mosques debate. Philosophy and Social Criticism 37(4), 383-392.

Göle, N. (2012). Decentering Europe, recentering Islam. New Literary History, 43(4), 665-685.

Göle, N. (2015). Islam and secularity: The future of Europe's public sphere. Durham NC: Duke University Press.

Graves, M. (2012). Feeling uncomfortable in the nineteenth century. Journal of Art Historiography, 6.

Greenberger, A. (2020, February 19). Louvre cancels Bulgarian religious art show amid row over emphasis on Islamic art influences. ARTnews.com. https://www.artnews.com/artnews/news/louvre-bulgarian-art-exhibition-canceled-1202678319

Grinell, K. (2020). Labelling Islam: Structuring ideas in Islamic galleries in Europe. In J. Norton-Wright (Ed.), Curating Islamic art worldwide: From Malacca to Manchester (pp. 31-44). Cham: Springer International Publishing.

Grinell, K., Berg, M., \& Larsson, G. (2019). Museological framings of Islam in Europe. Material Religion, 15(3), 370-371. 
Guidi, D. (2019). L'islam des musées: Sociohistoire de l'islam dans les politiques culturelles françaies. Les cas $d u$ Louvre et de l'Institut $d u$ monde arabe (Unpublished $\mathrm{PhD}$ thesis). University of Fribourg and École Pratique des Hautes Étude.

Güsten, S. (2011, May 25). Turkey presses harder for return of antiquities. The New York Times. Retrieved from https://www.nytimes.com/2011/05/26/world/europe/26ihtM26C-TURKEY-RETURN.html

Harmanşah, R., Tanyeri-Erdemir, T., \& Hayden, R. M. (2014). Secularizing the unsecularizable: A comparative study of the Haci Bektaş and Mevlana Museums in Turkey. In E. Barkan \& K. Barkey (Eds.), Choreographies of shared sacred sites: Religion, politics, and conflict resolution (pp. 336-368). New York: Columbia University Press.

Heath, I. (2007). The representation of Islam in British museums. Oxford: Archaeopress.

Henig, D. (2012). 'This is our little hajj': Muslim holy sites and reappropriation of the sacred landscape in contemporary Bosnia. American Ethnologist, 39(4), 751-765.

Herzfeld, M. (1991). A place in history: Social and monumental time in a Cretan town. Cambridge, MA: Princeton University Press.

Hirschkind, C. (2014). The afterlife of Moorish Spain. In N. Göle (Ed.), Islam and public controversy in Europe. Farnham, England: Ashgate Press.

Hodgson, M. G. S. (1974). The venture of Islam: Conscience and history in a world civilization. Chicago, IL: University of Chicago Press.

Janes, R. R., \& Sandell, R. (2019). Museum activism. London: Routledge.

Jouili, J. S. (2019). Islam and culture: Dis/junctures in a modern conceptual terrain. Comparative Studies in Society and History, 61(1), 207-237.

Junod, B., Khalil, G., Weber, S., \& Wolf, G. (Eds.). (2012). Islamic art and the museum:Approaches to art and archaeology of the Muslim world in the twenty-first century. London: Saqi Books.

Kadoi,Y., \& Szántó, I. (Eds.). (2013). The shaping of Persian art: Collections and interpretations of the art of Islamic Iran and Central Asia. Newcastle upon Tyne: Cambridge Scholars Publishing.

Kamel, S. (2013). Wege zur Vermittlung von Religionen in Berliner Museen: Black Kaaba meets White Cube. Wiesbaden: Springer.

Kamel, S. (2019). Diversifying Islam and the museum. Material Religion, 15(3), 374-375.

Kamel, S., \& Gerbich, C. (Eds.). (2014). Experimentierfeld Museum: Internationale Perspektiven auf Museen, Islam und Inklusion. Bielefeld: transcript.

Kaya. A. (2020). Populism and heritage in Europe: Lost in diversity and unity. London: Routledge.

Kemper, M. (2014). Ijtihad into philosophy: Islam as cultural heritage in post-Stalinist Daghestan. Central Asian Survey, 33(3), 390-404.

Kersel, M. M., \& Luke, C. (2015). Civil societies? Heritage diplomacy and neo-imperialism. In L. Meskell (Ed.), Global heritage (pp.70-93). New York:Wiley-Blackwell.

Kuppinger, P. (2015). Faithfully urban: Pious Muslims in a German city. New York and Oxford: Berghahn.

Kuppinger, P. (2019). Islam, vernacular culture and creativity in Stuttgart. In J.-J. Bock \& S. Macdonald (Eds.), Refugees welcome? Difference and diversity in a changing Germany (pp. 103-120). Oxford: Berghahn.

Labadi, S. (2018). Museums, immigrants, and social justice. London: Routledge.

Larsson, G. (2019). The Museum caught in a maelstrom of narratives: Exhibiting Islam in Europe. Bulletin for the Study of Religion, 48(1-2), 9-14.

Larsson, G., \& Spielhaus, R. (2013). Narratives of inclusion and exclusion: Islam and Muslims as a subject of European studies. Journal of Muslims in Europe, 2(2), 105-113.

Macdonald, S. (2013). Memorylands: Heritage and identity in Europe today. London: Routledge. 


\section{Mirjam Shatanawi, Sharon Macdonald and Katarzyna Puzon}

Macdonald, S. (2014). Migrating heritage, networks and networking: Europe and Islamic heritage. In P. Innocenti (Ed.), Migrating heritage: Experiences of cultural networks and cultural dialogue in Europe (pp. 53-64). Surrey: Ashgate.

Macdonald, S. (2016). New constellations of difference in Europe's 21st-Century museumscape. Museum Anthropology, 39(1), 4-19.

Macdonald, S. (2018). Heritage. In H. Callan (Ed.), The international encyclopedia of anthropology. New York: Wiley-Blackwell.

MacMillan, C. (2013). Discourse, identity and the question of Turkish accession to the EU:Through the looking glass. Abingdon: Routledge.

McLoughlin, S. (2014). Writing 'Bradistan' across the domains of social reality. In S. McLoughlin, W. Gould, A. J. Kabir, \& E. Tomalin (Eds.), Writing the city in British Asian diasporas (pp. 21-38). Abingdon: Routledge.

Mediano, F. R. (2013). Culture, identity and civilization: The Arabs and Islam in the history of Spain. In F. Peter, S. Dornhof, \& E. Arigita (Eds.), Islam and the politics of culture in Europe: Memory, Aesthetics, Art (pp. 41-60). Bielefeld: transcript.

Merdjanova, I. (2013). Rediscovering the umma: Muslims in the Balkans between nationalism and transnationalism. Oxford: Oxford University Press.

Modood,T. (2013). Multiculturalism, 2nd edn. Cambridge: Polity.

Moors, A. (2012). The affective power of the face veil: Between disgust and fascination. In D. Houtman \& B. Meyer (Eds.), Things: Religion and the question of materiality (pp. 282-295). New York: Fordham University Press.

Naguib, S. A. (2015). Materializing Islam and the imaginary of sacred space. In $\varnothing$. Fuglerud \& L. Wainwright (Eds.), Objects and imagination: Perspectives on materialization and meaning (pp. 64-78). Oxford: Berghahn.

Orzech, C. (2020). Museums of world religions: Displaying the divine, shaping cultures. London: Bloomsbury Academic.

Peter, F., Dornhof, S., \& Arigita, E. (Eds.). (2013). Islam and the politics of culture in Europe: Memory, aesthetics, art. Bielefeld: transcript.

Posocco, L. (2019). Museum politics in Turkey under the Islamic Justice and Development Party (AKP): The case of the Istanbul Museum of the History of Science and Technology in Islam. International Journal of Politics, Culture, and Society, 32(1), 83-103.

Puerta Vilchez, J. M. (2010). Reading the Alhambra: A visual guide to the Alhambra through its inscriptions. Granada: Generalife Trust \& EDILUX.

von Puttkamer, J. (2016). No future? Narrating the past in Bosnian history museums. Nationalities Papers, 44(5), 789-803.

Puzon, K. (2019). Participatory matters: Access, migration, and heritage in Berlin museums. In H. Oevermann \& E. Gantner (Eds.), Securing urban heritage: Agents, access, and securitization (pp. 31-46). London \& New York: Routledge.

Račius, E. (2020). Islam in post-communist Eastern Europe: Between churchification and securitization. Islam in post-communist Eastern Europe. Leiden: Brill.

Račius, E. (2018). Muslims in Eastern Europe. Edinburgh: Edinburgh University Press.

Reekum, R., van, Duyvendak, J. W., \& Bertossi, C. (2012). National models of integration and the crisis of multiculturalism: A critical comparative perspective. Patterns of Prejudice, 46(5), 417-426.

Reeve, J. (2017). Islam and museums: Learning and outreach. In G. Buggeln, C. Paine, \& S. B. Plate (Eds.), Religion in museums: Global and multidisciplinary perspectives (pp. 173179). London: Bloomsbury.

Reeve, J. (2018). Islam: Islamic art, the Islamic world - and museums. In S. Knell (Ed.), The contemporary museum: Shaping museums for the global now (pp. 55-73). London: Routledge. 
Rey, V. (2019). Islam, museums, and the politics of representation in the West. Material Religion, 15(2), 250-252.

Rico, T. (Ed.). (2017). The making of Islamic heritage: Muslim pasts and heritage presents. Singapore: Springer.

Rujanac, D. S. (2013) Ajvatovica: A bridge between tradition and national and religious identity. History and Anthropology, 24(1), 117-136.

Said, E. (1978). Orientalism. New York: Pantheon Books.

Sandell, R., \& Nightingale, E. (2012). Museums, equality, and social justice. London: Routledge.

Sarr, F., \& Savoy, B. (2018). The restitution of African cultural heritage:Toward a new relational ethics (No. 2018-26). Retrieved from http://restitutionreport2018.com/sarr_savoy_en.pdf

Shatanawi, M. (2012a). Curating against dissent: Museums and the public debate on Islam. In C. Flood, S. Hutchings, G. Miazhevich, \& H. Nickels (Eds.), Political and cultural representations of Muslims: Islam in the plural (pp. 177-192). Leiden: Brill.

Shatanawi, M. (2012b) Engaging Islam: Working with Islamic communities in a multicultural society. Curator: The Museum Journal, 55(1), 65-79.

Shatanawi, M. (2014). Islam at the Tropenmuseum. Arnhem: LM Publishers.

Shatanawi, M. (2021). On the in-betweenness of the paintings of Jean Baptiste Vanmour (1671-1737) at the Rijksmuseum. In S. Leeb \& N. Samuel (Eds.), Museums and the transcultural nation state: Case studies from a global context. Bielefeld: transcript.

Shaw, W. M. K. (2010). Between the secular and the sacred: A new face for the department of the holy relics at the Topkap1 Palace Museum. Material Religion, 6(1), 129-131.

Shaw, W. M. K. (2019a). Signs of empire: Islamic art museums from European imperialism to the global empire of capital. In M.W. Gahtan \& E.-M. Troelenberg (Eds.), Collecting and empires:An historical and global perspective (pp.354-371).Turnhout: Harvey Miller Publishers.

Shaw, W. M. K. (2019b) What is 'Islamic' Art? Cambridge: Cambridge University Press.

Shryock, A. (2019). In double bind: A conversation with Jeanette Jouili, Mucahit Bilici, Esra Özyürek, and Kabir Tambar about Islam and the culture/religion binary. Retrieved from https://cssh.lsa.umich.edu/2019/01/19/double-bind/

Spielhaus, R. (2013). Narratives of belonging and exclusion: Offering the Museum of Islamic Art as a lieu d'identité for Muslims. In F. Peter, S. Dornhof, \& E. Arigita (Eds.), Islam and the politics of culture in Europe: Memory, aesthetics, art (pp. 75-92). Bielefeld: transcript.

Tamimi Arab, P. (2017). Amplifying Islam in the European soundscape: Religious pluralism and secularism in the Netherlands. London: Bloomsbury Academic.

Tamimi Arab, P. (forthcoming). Islamic heritage versus Orthodoxy: Figural painting, musical instruments, and wine bowls at the Dutch National Museum of World Cultures. Journal of Material Culture, 26

Ünsal, D. (2019). Positioning museums politically for social justice. Museum Management and Curatorship, 34(6), 595-607.

Veer P. van der, (2002). Transnational religion: Hindu and Muslim movements, Global Networks, 2(2), 95-109.

Velioğlu, H. (2013). Fugitive or cosmopolitan: The Bosniaks' desire for Europe and the trouble with the Ottoman past. In N. Göle (Ed.), Islam and public controversy in Europe (pp. 241-256). Farnham: Ashgate.

Vernoit, S. (Ed.). (2000). Discovering Islamic art: Scholars, collectors and collections, 1850-1950. London: I.B. Tauris.

Vertovec, S., \& Wessendorf, S. (Eds.). (2009). The multiculturalism backlash: European discourses, policies and practices. London: Routledge. 
Watenpaugh, H. Z. (2017). Resonance and circulation: The category 'Islamic art and architecture'. In F. B. Flood \& G. Necipoğlu (Eds.), A companion to Islamic art and architecture: Vol. II (pp. 1223-1244). Oxford: Wiley Blackwell.

Whitehead, C., \& Bozoğlu, G. (2015). Constitutive others and the management of difference: Museum representations of Turkish identities. In C. Whitehead, S. Eckersley, K. Lloyd, \& R. Mason (Eds.), Museums, migration and identity in Europe: Peoples, places and identities (pp. 253-284). London: Routledge.

Winegar, J. (2008). The humanity game: Art, Islam, and the war on terror. Anthropological Quarterly, 81(3), 651-681.

Yemelianova, G. M. (2016). Muslim-state relations in Russia. In R. Mason (Ed.), Muslim minority-state relations: Violence, integration, and policy (pp. 107-132). London: Palgrave Macmillan. 